\section{Peonza y vergïienza del Leviatán}

\section{Raciel D. Martínez Gómez}

a presencia en Dunkerque (2017) del actor inglés Kenneth Branagh interpretando al circunspecto comandante Bolton, a cargo del muelle para la evacuación de la playa de la ciudad francesa, cumple el mismo rol que la peonza que introduce el sueño en El origen (2010), ambas películas dirigidas por Christopher Nolan. El tótem era una suerte de clave para saber si estábamos en el mundo onírico de la repetición infinita. Por ello la peonza, cuando aparece en el sueño, no termina de dar vueltas. Pese a ello Nolan, que había marcado esa sutil distinción como pista hacia el espectador, prefiere un final ambiguo que anula la posibilidad de significado de la peonza.

El cineasta, como lo acostumbraron grandes como Luis Buñuel o David Lynch, no justifica su deliberada provocación colocada en el punto de inflexión del filme. Posteriormente Nolan explicó que poco importaba que nadie se enterara de que El origen no concluye de manera objetiva, que lo más importante era sostener su tesis: que la construcción de la realidad, siempre, será un acto subjetivo. El episodio de Dunkerque, por su ambiente claustrofóbico reforzado con una también meditada invisibilización política del enemigo, semeja un mal sueño. Según los testimonios, fue una auténtica pesadilla para los sobrevivientes. Winston Churchill describía la inminente pérdida como una afrenta mayor a la fuerza británica; de ahí que la evacuación de la metafóri-

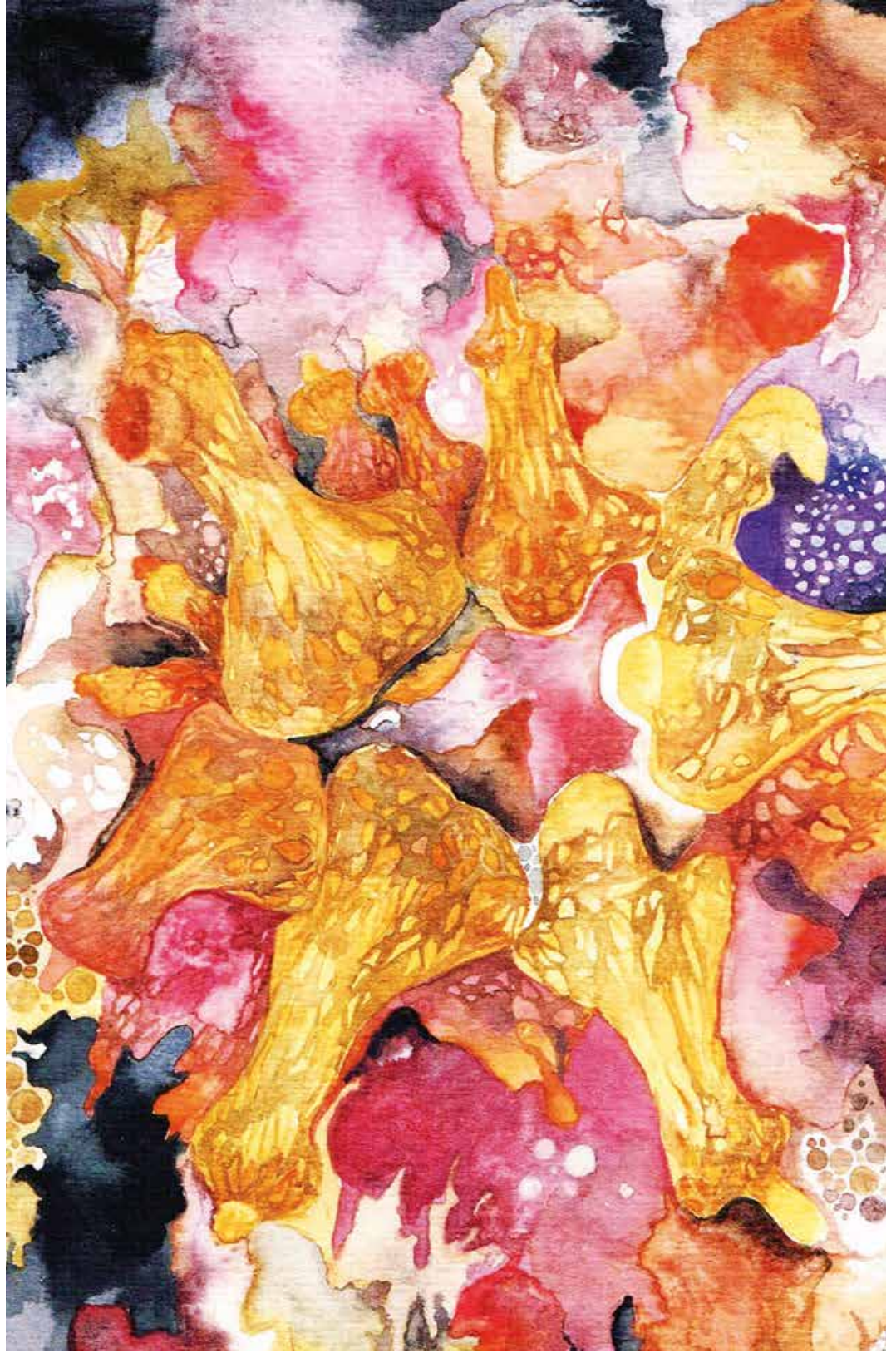

Aqua. De la serie Universos internos

ca ratonera fuese calificada por el ministro como "milagrosa".

Bolton, impávido, antepone una paciencia estoica al ubicuo ataque de la Luftwaffe que contenía cualquier intento de escapatoria. Se trata de un enemigo que carece de rostro, incesante e imposible de evitar. Los alemanes parecen brotar de un contexto dormido; los pilotos, inclusive, no se desarrollan como historia propia en contraste con los dra- mas de los soldados acorralados. La súbita aparición de los enemigos se repite con la misma eficacia de la peonza que gira cuando Dom Cobb (Leonardo DiCaprio) se reencuentra con su familia en El origen.

La eventual fuga de la playa es repelida una y otra vez por estas presencias exactas en el aire, lo que aumenta de forma evidente la frustración. Las víctimas exhiben propensión a ser culpadas por una 
